\title{
液状ポリブタジエンの静電場内での変形挙動*
}

\author{
京都工芸䋐維大学高分子学科 北尾敏男・基村雅洋・中西康之 \\ 木村良晴・谷口五十二
}

\section{THE DEFORMATION BEHAVIOR OF LIQUID POLYBUTADIENE IN VARIOUS ELECTROSTATIC FIELDS}

\author{
By Toshio Kitao, Masahiro Kimura, Yasuyuki Nakanishi, \\ Yoshiharu Kimura and Isoji Taniguchi \\ (Department of Polymer Science and Engineering, \\ Kyoto Institute of Technology, Matsugasaki, Kyoto, 606)
}

The deformation of a viscous liquid polybutadiene (LPB) drop in an electrostatic field was studied. Three types of electrodes, i.e., a thin plate, a single-needle, and a twin-needle electrodes, were employed in connection with a stabilized high voltage DC source. A PTFE-coated aluminum plate (a counter-electrode) was horizontally settled and connected to the above-mentioned electrode via the high voltage source. A drop of LPB was allowed to stand on the PTFE surface of the counter-electrode and one of the three electrodes was placed above the drop. The LPB drop was deformed responding to the magnitude of the electrostatic field and the deformation manner directly reflected the electrode employed. When the drop was placed between a couple of plate electrodes, it merely behaved as an insulator in a capacitor. The use of the single-needle electrode caused a deformation to doughnut-shaped drop. The most complicated deformation behavior was observed for the twin-needle electrode system: If a gap between the needles, $d$, was longer than the initial diameter of the drop, $w_{0}$, the drop expanded in the direction perpendicular to the needleto-needle direction. If $d$ was shorter than $W_{0}$, however, the expansion was more significant in the needle-to-needle direction than in its perpendicular direction. It is concluded that the coulombic forces, which act between charges stored or induced on the drop surface and the PTFE substrate, resulted in the deformation of the LPB drop.

(Received May 30, 1984)

\section{1. 緒}

\section{言}

前報 ${ }^{1}$ で，Tダイ押出製膜機のエアナイフの代りに針 状電極を取付け，この電極に $4 \mathrm{kV}$ 以上の電圧を印加する と、下ダイから押出され溶融状態にある高密度ポリエチ レンフィルムの幅が拡がり，厚さか溥くなるととを報告 した。この幅の拡がりは，針状電極から生ずるコロナ放 電により,フィルムの両面が帯電し，との電荷間作用 するクーロンカにより走行フィルムが厚さ方向に压縮さ

\footnotetext{
“本報文を「静電場内でのフィルム成形第 2 報」とする。 This paper is the part II of the series of the studies entitled "Flat-Film Processing in Electrostatic Field".
}

れる結果としてひき起されたあのであると推定した。

本報は，との静電場内での高分子融体の変形挙動をよ

り正確に解明することを目的とし，溶融ポリエチレンの 代りに, 室温で流動可能な液状ポリブタジエン(以下LPB と略記する)を用い，とれを 3 種の構造の異なる電極内 で変形させるととにより得られた結果について述へる。

\section{2. 実験}

\section{1 供試物}

前報”では，Tダイから押出された溶融状態の高密度 ポリエチレンフィルムが静電場を通過する際の変形挙動 を倹討したが，実験をモデル化して測定をより容易にす る目的で、液状ポリブタジエン（日本ゼオン Poly-oil 130） 
に小量の顔料を添加したものを使用した。

\section{2 電 梗}

3 種の笔極を使用した。(1)厚さ $0.03 \mathrm{~cm}$ ，緥横とるに $2.5 \mathrm{~cm}$ のアルミ板を平板電極として使用した。（2）硬質 透明塩化ビニル板 (縦 $8 \mathrm{~cm}$, 横 $8 \mathrm{~cm}$ ，厚さ $0.3 \mathrm{~cm})$ の中 央に, 長さ $2.6 \mathrm{~cm}$ 直径 $0.075 \mathrm{~cm}$ の針を 1 本だけ植え單針 電極とした。（3）同し大きさの塩化ビニル板の中央線上 に，同し寸法の 2 本の針を種々の間隔で植え，これらの 針を銅線で接続した。これを 2 針電極之呼ふ。対電極に は，一面をポリ 4 フッ化エチレンでコーテングされた， 一边の長さが $10 \mathrm{~cm}$ の正方形のアルミ板( PTFE-AL板) を使用した。実際のTダイ押出棘膜実験では，クロムめ つきした铁ロールを接地して対電極としたが，LPBをア ルミ板上に直接置くと，その表面エネルギーの差異のた めに，LPBはアルミ板上で拡がり液滴を形成しない。 したがって、LPBより表面エネルギーの小さいPTFE 面上にLPBを乗せた。

\section{3 面流高電正発生装置}

岩田高圧研究所䌘の直流高王安定化電源を使用した。 陰極コロナに比して，陽極コロナは空気中に含まれる水

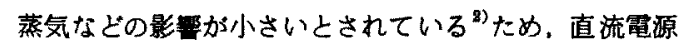
には+30 kVまでの電圧を発生し得る装置を使用した。 また，本装置は，回路が短絡したり火花放電するととに より過大電流が流れた場合には，安全装置が作動し，眼 時に電流が停止する機構を内蔵している。

\section{4 測 定}

実験装置の組立図を図1に示す。PTFE面が上を向く ように対電極板を水平に設置し，その一端に銅楾ケーブ ルをつなぎ、との先端を接地した。スポイドを用いて LPBをこの対笔極板のほほ中央に乗せた。PTFEの表 面エネルギーはLPBの表面エネルギーよりす小さいので，

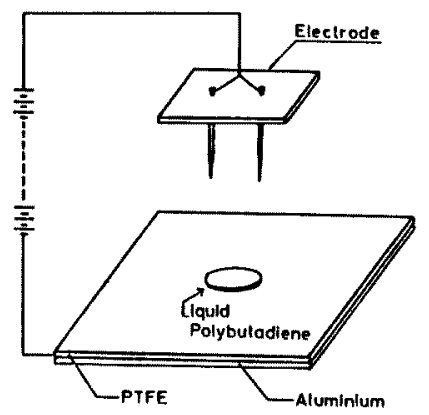

Fig. 1. A schematic representation of the apparatus used. A drop of liquid polybutadiene (LPB) is placed on a PTFE sheet covering an aluminum plate, which is grounded to complete an electric circuit.
これらの接触角は鈍角となり，LPBは速やか亿一定直 径の液滴となった。液滴の直径が約 $1 \mathrm{cml}$ にるよう滴下 贯を調節した。この時，液滴の高さは約 $2 \mathrm{~mm}$ であった。 この液滴の上方に電極を設置した。電極針は下方にあ る液滴を指すようになっており，電極の位圈は，前後左 右さらには上下に可動となっている。カセトメータを使 用して，LPB 液滴の中心と電極の中心とが一政するよ うに，電極の位置を調節した。電極は直流電源に接続し た。これらの莣置は(図 1 では省略されているが)，安全 のためにポリメチルメタクリレート箱の中に納めた。 ただし，液滴の動きを観察するために，この格納箱の前 面と側面に必要最小限の穴をあけた。測定は室温でおこ ない，液滴の大きさはカセトメータで読み取った。

\section{3. 結果および考察}

\section{1 平板雷栖}

平板電極を用いた場合の液滴の変形挙動を図 2 に示し た。印加電代加低い場合には，図2，、、に示すように，液 滴は扁平な形をしている。印加軋代を高くすると，圀2， bに示すように，液滴の直径が滅少し，その高さが增大 する。さらに電生を高くすると，液滴は柱状を呈するよ うになり，やがて図2，cのように両電極間をつなぐ形と なる。この間，当然のととながら，両電極間にコロナは 観察されず、したがって電流はまったく流れなかった。 上方にあるアルミ電極に接した後，LPBは両電極間 を往復するようになり，やがて両電極間に火花放要が起

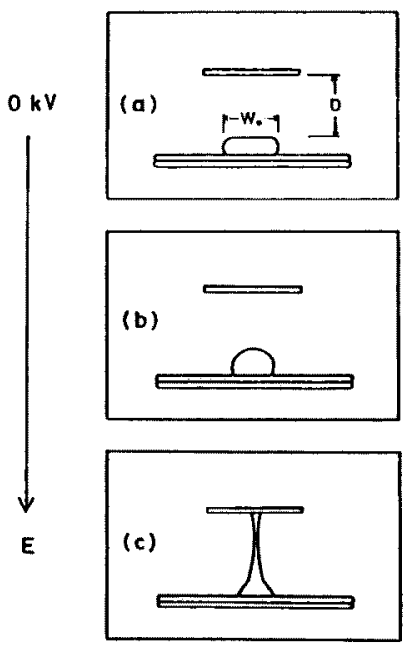

Fig. 2. Side views of a LPB drop deforming between parallel plate electrodes. With increasing applied voltage $E(a \rightarrow b \rightarrow c)$, the drop swells, elongates vertically (b), and finally reaches the counter plate (c). 
り、高再電源が停止し元の図2, a の状慜に戻った。

このような举動は，両電極がコン゙ンサーとなったと とを示している。すなわち，丁ルミ板と PTFE-AL板 とがコンデンサーを形成しており，との間焢気と，LPB 液滴が䋓縁体としてはいっているととになる。平板電極 に正電圧を印加すると，LPBは電気的に分極を起し， その表面には負龟荷か，またPTFEと接している底面に は正電荷が誘導される。この誘導電荷量は，電正ととも に增加し，やがて波滴表面に蓄えられた負電荷とアルミ 板上に印加された正軋荷間に働くクーロンカか力液滴の重 量を上迴るようになると，液滴はアルミ平板電極に向っ て吸い上げられる。アルミ平板電極上でLPBは電荷を 失い対電極上に落下することになる。

てのような原理を高分子の成形に応用した例としては， Larrondo ${ }^{3 \sim B)}$ による電場内での溶融䄱系を挙げるて とができる。さらに，実用化されている例としては，1 ンクジェット方式による用刷を挙げることができる。

\section{2 単针電桓}

図3に模式的に示したように単針電極を用いた場合に 6、盺加電圧が低い場合には液滴は変形しなかった。電 極の位置にもよるが，印加電任が 4 5kVk達すると， 電極針の先端にグロー・コロナが観察されるようになり， 液滴の中心部がわずかにくほみ，その直经が大きくなり はじめる。印加電印をさらに高くすると中心部のくはみ がより深くなり，やがて液滴は環状を呈するようになっ

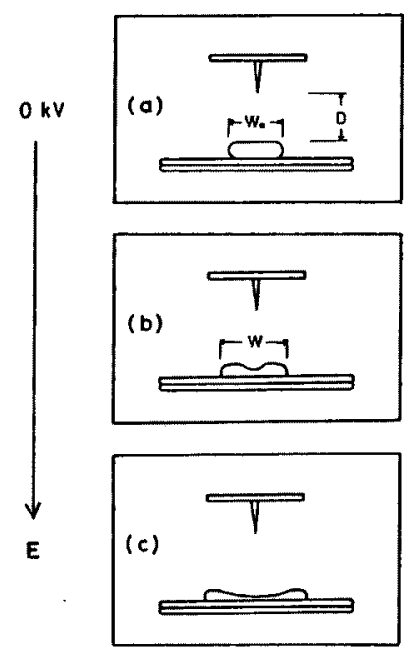

Fig. 3. Side views of a LPB drop deforming between a single-needle electrode and a plate electrode as the voltage $E$ increases $(a \rightarrow b \rightarrow c)$. A concavity is formed at the central part of the drop (b) and the drop spreads at higher voltage (c).
た。との間液滴の外径は增大しつつけた。引き続き電圧 を高くすると，ストリーマ・コロナ領域汇達して環の外 径は最大となり，最後䎲火花放䉓が起った。1本の笔極 針加ら生ずる電界は，陽極コロナの場合には，コロナか 伸展し樹枝状コロナに生長するため，かなり広い範囲に

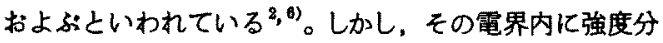
布か存在し，電極針の延長方向すなわち液滴の中心部の 電場強度加最大であるあのと考元られる。液滴の厚さは その中心部で最大となっているにすかかからず，そとに 付加される正電荷密度が最も大きく，したがって対電極 表面の相当する部分唀起される負電荷の密度も最大と なるために，液滴の中心部にかかるクーロンカが最む大 きくなり，液滴は周辺部に向って押拡げられ環状構造に 変ってゆくものと推定される。

単針䉓極を使用した場合の町加電生 $E$ とLPB環の外 径W との関係を図 4 亿示す。図からWの変化は 4 つの領 域に分けられるととが明らかである。第 1 領域は，変形 がまったく起らず $(d W / d E)=0$ となる領域である。と の領域内では，電極間を流れる電流も極めて少なく，电 気工学的には暗電流領域と呼ばれている゙”。Eか降伏電 王 $E_{y}$ を越えるとグロー・コロナ領域に入り，(dW/dE)

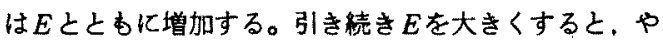
がて $(d W / d E)$ は一定值をとるようになる。との領域を 第 3 領域とする。第 4 領域では，ストリーマ・コロナと 呼はれれる電極針と液滴表面とをつなぐコロナが発生し， 電流す增加するが $(d W / d E)$ は減少し，Wは濑次一定值 に近つく。一般的には，グロー・コロナにつふいてブう シ・コロナが現われるとされているが，本研究の場合に は，電極針の先端から波滴表面までの距離が $20 \mathrm{~mm}$ 以下 であったために、ブラシ・コロナは観察されなかった。

Dが小さい時にはとのような変化は比較的低電圧で起 り，逆にDを大きくすると，各領域に相当する軋圠す高

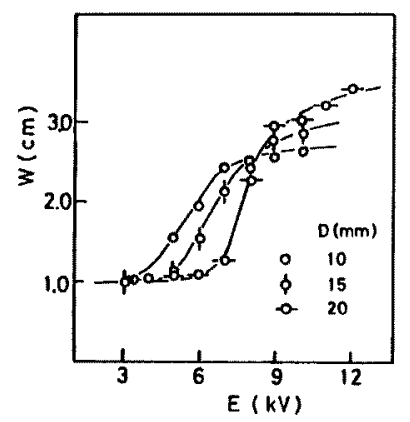

Fig. 4. Plots of the outside diameter of a LPB drop $W$ against the voltage $E$ applied at various single needle-to-drop distances, D. $W$ and $D$ are indicated in Fig. 3. 
正側に移るととが図 4 から明らかである。さらに興味深 いととに，Dを大きくすると $E_{\mathrm{y}}$ 加增加しコロナが発生 しにくくなるが，第 3 領域の傾き $(d W / d E)$ 枋よび第 4 領域のWが大きくなる。この事実は，䉓極間距離 $D$ を長 くするとコロナは発生しにくくなるか，コロナの拡がり が大きくなるととを意味している。したがって，Dを長 くした場合には，Dが短い場合に比して低印加電王下で は液滴の搪がりは小さいが，高電代を凅加するとより大 きな拡がりが得られるととになる。

\subsection{2 針雷梗}

この電極を使用した場合には，液滴の初期直径 $W_{0}$ と 電極針間の距離 $d$ との大小関係化上り, 液滴の变形挙動 は異なった。

\subsection{1 dが $W_{0}$ より大きい場合}

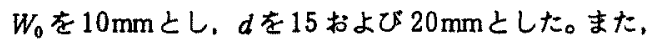
奄極針先端から液满の初期メニスカスまでの距䌖 $D$ は， 15 および $20 \mathrm{~mm}$ とした。

印如電圧 $E$ が $E_{\mathrm{y}}$ を越えると，針端にグロー・コロナ 加発生し，LPB液滴は 2 本の電極針を結か力向上直交 する方向に伸びはじめる。図 5 は，てのような液滴の形 状の変化を直上からスケッチしたあのである。すなわち， 図 5、aの円は液滴を表わしており，その上下に描加九た 小円は電極針を示している。 $E$ が $E_{\mathrm{y}}$ を越えグロー・コ

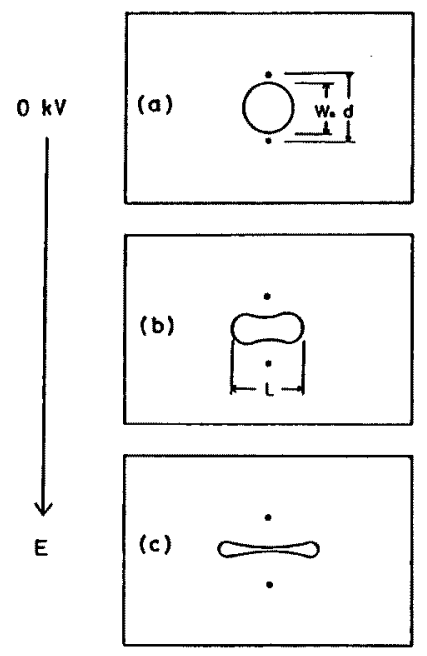

Fig. 5. Top views of a LPB drop deforming between a twin-needle electrode and a plate electrode as the voltage $E$ increases $(a \rightarrow b \rightarrow c)$. A pair of small circles represent the twin-needle electrode. Note that the distance between both needles $d$ is longer than the initial diameter of the drop $W_{0}$. ロナが発生すると，四5、bに示したように，湤滴は伸ひ はじぬる。さらにEを大きくすると、ストリーマ・コロ ナが観察されるようになり，液滴はその中央部で分裂す る。

てのような変形挙動は以下のように説明するととがで きる。すなわち，電極針からコロナ・シャワーとして通 ばれてきた正電荷は対電極板の表面に蕃えられる。3.2 項で述べたうに，対電極板上の正電荷密度は電極針直 下の点を中心としてほぼ円形に分布しており，ちの中心 部で最大であり中心から逗ざかるにつれ次第に減少する あのと推定される。本実験のように，2針電極を $d>W_{0}$ となるように取付けた場合には。コロナとして運はれれて きた正電荷の多くは対電極板の電極针直下の部分を中心 点として蓄えられるか，その一部はLPB 液滴の電極針 に近い部分(図 5,aでは液滴として描かれた円の上下の 部分)にも蓄えられる。この上うにして，電極板のPTFE 上および LPB 液滴上に局所的に正電荷が分布するとと もに，電極板のアルミ層の相当する部分にも相当量の負 電荷加誘起されるとととなり，LPB液滴には次の三種 のクーロン力が作用する。1)液滴上に蓄えられた正菓荷 と電極板中に誘起された負電荷間に勳くクーロン引力 $f_{1}$ ， 2) 液滴の 2 個所に蕃えられた正電荷間仁作用するクーロ ン质力 $f_{2}$ ，および 液滴上の正電荷とそれに隣接する PTFE上の正電荷間のクーロン质力 $f_{\mathrm{B}}$ が同時に液滴に 作用し、液滴加変形するすのと推定される。

電極針からの距離およびれぞれの電荷間の平均距䊒 を考虑すると， $f_{3}$ に比して $f_{2}$ は極めて小さいすのと考 えられる。したがって，液滴の帯電した部分は $f_{1}$ により 厚さ方向に圧縮され拡が万うとする。しかし，電極針を 結ふ方向には $f_{3}$ が作用しているために動くことができ ず(むしろ $f_{\mathrm{s}}$ により开縮されて)帯電していない方向(図 5、aでは横方向)にのみ搪がるものと推定される。

四 6 K，印加電压 $E$ と液滴の長さ $L$ との関係を示す。 $E$ が $E_{\mathrm{y}}$ を越え自続性コロナ領域に達すると，波滴の伸 長がはじまり，Eの增大によもないLは単調增加する。 また，電極針と液滴との垂蹎距離 $D$ を長くすると，液滴 の伸長速度 $(d L / d E)$ は大きくなった。との事実は単針 電極の項でも述べたように，電極針から生じたコロナは 針端から遠ざかるにつれ拡がった電界を形成していると とを示唆している。したがって、Dが短い場合は, PTFE 上にはより多量の正電荷があたらされるが，LPB液滴 上に到荤する正電荷は比較的少なく，電荷間の哌力功小 さくなり液滴は搪がりにくくなるもの之推定される。

$3.3 .2 d か ゙ W_{0}$ より小さい場合

単針電極による場合と類似した変形挙動を示す。図 7 に，変形の様子を模式的に示した。 $E$ が $E_{y}$ を越えるよ， 


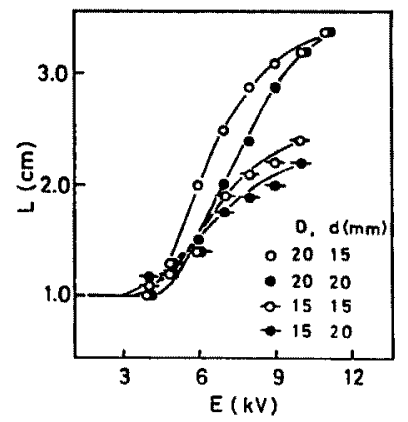

Fig. 6. The variation of the length, $L$ of a LPB drop with voltage $E$ applied between a twin-needle electrode and a plate electrode. The distance between both needles $d$ is longer than the initial diameter of the drop $W_{0}(=1.0 \mathrm{~cm})$.

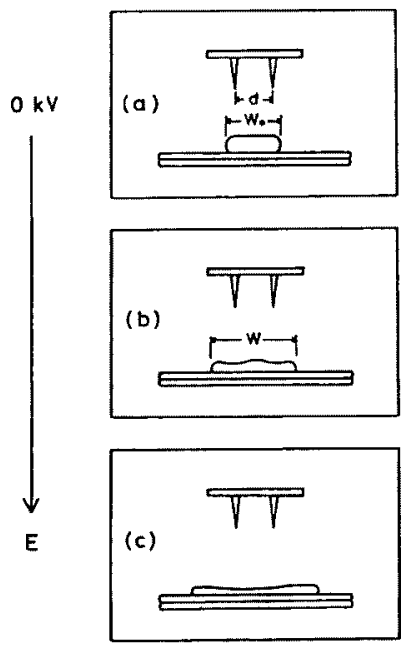

Fig. 7. Side views of a LPB drop deforming between a twin-needle electrode and a plate electrode as the voltage $E$ increases $(\mathbf{a} \rightarrow \mathbf{b} \rightarrow \mathrm{c})$. Note that the initial diameter of the drop $W_{0}$ is longer than the distance between both needles $d$. The top view of the drop changes from circle to ellipse with the applied voltage.

電極針直下の部分がくぼみはじめ，液滴の搪張がはじま る。单針電極を使用した場合には，液滴の横断面は常に 円であったのに反し，この場合には，電極針方向の拡が りの方が，それに直交する方向の搪がりよりも大となり 液滴の横断面は円から棈円になった。Eを増しつつける と，電極針直下に生したくはみは生長し，やがて，連結 し1個の長いくほみとなった(図 7，c)。

図 8 K，電極針先端加ら液滴表面までの距離 $D$ を $3 \mathrm{~mm}$

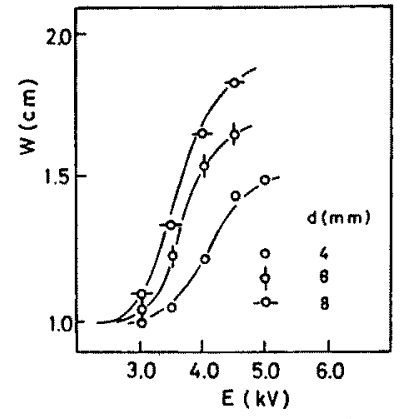

Fig. 8. A relation between the applied voltage $E$ and the length of the major axis, $W$ of the LPB drop elliptically deformed, as shown in Fig. 7, as a function of distance between the two needles $d$, which was chosen shorter than the initial diameter of the drop $W_{0}$.

に固定し，電極針間の距離 $d$ を $4 \mathrm{~mm}$ から $8 \mathrm{~mm}$ の範用で 変えることにより得られた結果を示した。Dおよびdを 短かくした理由は、コロナのおよふ籁围を液滴表面上に 限定するためである。PTFE表面に電荷が蓄積されると， 先述したように，液商の拡がりに制約が生じ，应張率が 低下するとともに，㹡張の再現性がとぼしくなった。

$D か ゙$ 短いため，低電王でコロナが発生し， $E_{\mathbf{y}}$ は約 $3 \mathrm{kV}$ となった。 $d$ が大きくなるにつれ $(d W / d E)$ が增大し， $W$ b大きくなった。 $d$ が小さい場合には，2本の電極針 により形成される電界の大きさは，単針電極を使用した 場合に近つき， $d$ を大きすると，電界がそれぞれ独立 して形成されるためにてのような結果になった向のと推 定される。しかし，液滴は針を結ぶ方のみでなく，そ れと直交する方向にあ摭張された。しかし，ての方向へ の拡がりは，針方向への拡がりに比して小さかった。

$d$ が小さい場合には，液滴表面に印加された正電荷相 互の反発により，液滴はより大きく拉張されるすのと予 想された。事実，LPBよりも粘性係数の低いヒマシ油 を用いた同様な実験では，dが狭くなるにつれWの変化 は大きくなった。恐らく供試物の粘度や導電性などによ り変形挙動が異なるものと考えられる。

\section{4. 結 論}

自続性コロナが発生するとLPB 液滴は変形されるこ とが明らかになった。電極針を 2 本とし，それらの間隔 $d$ を液滴の初期直径 $W_{0}$ より大きくすると，液滴は針方 向上直交する方向に大きく伸長される。一方， $d$ が利 上り小さい場合には，液滴は主として針方向に搪げられ 棈円となる。恐らく，Tダイ押出しされた溶融状態にあ る走行フィルムが拡幅される機構は， $d<W_{0}$ の場合上同 
じすのと推定される。したがって，前報”で推定したよ うに，走行フィルム表面に電荷が付加された結果として， その裹面に翼符号電荷か誘導され，これらの間作用す るクーロン引カがフィルムを代ぱくしその幅が拡くなる もの上考元られる。

とのような，静電引力により変形が起るとするならば 供試する高分子の電気的性犋，ととにその導電性により 变形度が異なる上考えられる。また，同一の電気的性犋 をそなえていてす，その溶融粘度によってい変形倍率か 異なるはずである。このような見地から，種々分子量の 異なる高分子を静電場で $\mathrm{T} タ ゙ イ$ 押出し製膜し，その拡が りについて検討を試みることは大変興味深く思われる。 付記：本研究の一部は，䋐維学会昭和 58 年度秋期研
究発表会(福井大学)において発表した。

$$
\text { 文献 }
$$

1）北尾敏男，下原秀介，中西康之，山元一正; 織学誌, 40, T-241 (1984)

2) 烏山四郎他; 改訂高電圧工学（標準軋気工学講座, 第 9 巻) p. 46, コロナ社 (1969)

3) L. Larrondo and R. ST. John Manley; J. Polym. Sci., Phys. Eddit. 19, 909 (1981)

4) L. Larrondo and R. ST. John Manley: ibid, 19, 921 (1981)

5) L. Larrondo and R. ST. John Manley: ibid, 19, 933 (1981)

6）原 大重；高電王現象， p. 57，森北出版 (1977) 